\title{
Noget om beskaffenheden af Bjelkes romaner
}

\author{
Per Stounbjerg
}

\section{Befriede ord}

Skriver Henrik Bjelke overhovedet romaner? Er det ikke søgt at bruge genren som indgang til et forfatterskab, der ikke respekterer genreskel? Hvad er fællesnævneren mellem Trap, Saturn, Solo nolo m.fl. ${ }^{1}$ og romaner som Lykke-Per, Himmel og helvede eller Tugt og utugt $i$ mellemtiden? Bjelkes personer får ikke fylde, selv om vi kommer tæt på dem, ydre handling er det så som så med, og forløbene er fragmenterede, flerstrengede og uden klar kausalitet. De enkelte kapitler kan ofte stå alene som prosadigte, skitser, essays, mystiske hymner etc. Teksterne synes kort sagt at savne romanens episke kvaliteter.

Enkelthedernes selvstændiggørelse fra de organiske helheder er konstateret i de sidste 200 års litteraturhistorie. Bjelke fører processen et skridt videre, idet han tillægger ordene en egenværdi, vi bedst kender fra lyrikken. Solo nolo indledes af et sætningsemne, der på to sider leverer et veritabelt katalog over kulturelle afarter af den topos, der angives med de tre første ord:

Den enlige herre, den ensomme melankolske, den fornægtede, den forældreløse [...] børnehjemsbarnet, vajsenhusbarnet, regensalumnet, [...] udskuddet, emigranten [...], idioten, drømmeren, gøgleren, solisten [...] den latent lovløse [...] menneskeflokkens Benjamin [...] den exilerede fyrste på strandbredden [...] han der på lazaretterne bader soldaternes sår i klor og siger digte så lange og messende at de sårede lindres, de bange sover, de døende afklares [...] (Bjelke 1986:7 f.) 
Denne optakt skal ikke bare fremstille et sagsforhold. Den er for meget, en næsten rabelaisk exces, der lader billedernes knopskydning bryde al narrativ økonomi. Nye ord føjer ikke nødvendigvis ny mening til, de er der blot i deres egen ret. Bjelkes romaner, for det er de trods alt, rummer en usædvanlig kærlighed til ordene - ikke mindst de løjerlige, preciøse, raffinerede, arkaiske eller eksotiske. Et kapitel i Hundrede postkort fra Helvede hedder simpelthen "Ord". I Bjelkes opremsninger gøres pleonasmen til et plus. Selektionen synes suspenderet i strømmende orgier af ord:

Men som ventet og sædvanlig ved den slags skærmydsel, var der næsten ikke den skavank, skabilken, makketut, badulje, dingenot, falbelade, farvelade, fastelavn, galimatias og resten af udtrykkene, der ikke lavede rabalder, kallevaps, kloduns, pladask, krambambuli og derved fik slampamper og hjertekvababelse midt under hele molevitten. (Bjelke 1980:109)

Ofte gør den sprænglærde Bjelke sin sproglige kunnen til mani. Meningen er vel, at fokus skal forskydes fra det betegnede til det materielle udtryk. Illusionsbruddet, fiktionens friktion, er den måde, hvorpå teksten gør opmærksom på sin egen kunstlethed. ${ }^{2}$

Ordene er trådløse. Deres punktuelle intensitet bryder den episke kontinuitet. I stedet for handlingens røde tråd træder den litterære tekstur i "en uendeligt sammenvævet flade". ${ }^{3}$ Forbindelserne skabes ud fra ordenes fysiske skikkelse. I Trap er et surreelt associationsforløb struktureret over alfabetet, ${ }^{4}$ vi går ind omkring ' $\mathrm{k}$ ':

Kemikers drøm: fødderne opløses i magnium. Om natten laver hofråd kemiske forsøg med lampe. Kejserpære kalder han den. „Kirschen sind drin". Hans klaverspil blir udpræget forsømt. Klaveret aldrig stemt. Klosethul. Skarnbunker. Knödel i krokøkkenet. Kuffert med bøger. Kurv smides ind gennem vinduet. Kvinde hugger hovedet af sagfører. Kærlighedstjenester på lazaret. Køleapparat som slynges bort. (Bjelke 1970:39)

Andetsteds er det endelserne, der forener, "ceremoniellet, intervallet, krystallet, chatollet", 5 eller de fælles franske rødder: 
"filet, gelé, etui, ragout, chakot, buffet" (Bjelke 1980:108). Semantiske isotopier, intertekstuelle trevler, associationer, anagrammer, rim, rytme, prosodi organiserer teksterne. Med ord, der er meningsløse, men suggestive, og som holdes sammen af en uforstyrret syntaks og en klar og selvsikker diktion, afsøger Bjelke forståelsens randområder: "En splintz er en knøkke med apt forke og fænket grenkapfel. Til brug ved strelinger i mørke og halvmørke norlinger tjønker man forken og kranker grenkapfelen. I apt vejr og i fænkede tidszoner udsender splintzen kerfler, så strelingerne kan gennemføres også i lyse norlinger, hvilket er et kongt fremskridt i forhold til den kendte knøkke" (Bjelke 1986:47 f.). 6

Ordene strømmer rablende og eruptivt. Deres kontinuum skaber kontakt til det store forskelsløse, en skrift uden ophav, begyndelse og slutning. Men den verbale ekshibitionisme lurer: ordene synes at være vehikler for en subjektiv ekspressionstrang, der er romangenren fremmed.

\section{Sproglige saturnalier}

Karakteristisk for romanordet er dets indirekte karakter, hævder M. Bakhtin. Det er ikke kun ekspressivt, et subjekts udtryk, og ikke kun afbildende; tværtimod bliver det selv genstand for afbildning. Romaner objektiverer andres sprog og stil i deres historiske relativitet og ufuldkommenhed. De er dialogiske og pietetsløse; de har ikke ét homogent sprog og én stil, men er systemer af sprog, der belyser hinanden (Bakhtin 1981:47). Repræsentationen af andres ord gør dem flerstemmige. I den citerende, parodiske, ironiske eller travesterende gengivelse af andres tale flyder grænserne mellem det egne og det fremmede. ${ }^{7}$

Bakhtins beskrivelse af romanen kunne være en karakteristik af Bjelkes prosa. Han er nemlig ikke altid "lost i sprogets uvirkelige operalibretto" (Bjelke 1980:20). Nok tales der direkte og ekstatisk, men det er ikke kun fortælleren, vi hører, og den strømmende tale bliver tilmed selv italesat. Det sker i den kulturkritiske udlægning af verbalismen som symptom på en tabt dialog.I den moderne hyperrealitet, Bjelke beskriver, møder 
subjektet intet objekt og ingen virkelighed, her knepper man tomme billeder og tegn i stedet for hinanden: „Definitionen på det nye menneske, en elektronikkens Proteus: en psykose med broerne til fænomenet 'andre mennesker' brændt bag sig". En autistisk menneskehed synes "fanget ind i en narcissismes lukkede pseudokommunikerende masturbationsrum" (Bjelke 1980:117 f.). ${ }^{8}$ Ex negativo påkalder Bjelke en dialogisme à la Buber eller adornitiske teorier om objektets forrang.

Bjelkes kulturkritik står selv i anførselstegn, de just omtalte pseudokommunikerende masturbationsrum er således en generalprøve på, hvad hovedpersonen i Hundrede postkort fra Helvede ville sige til en læge. De indgår i en citeret tale. Udladningerne af ord står ikke altid for fortællerens regning. Protokolleringen af alenemænd på de første sider i Solo nolo tilskrives hovedpersonen Hector, der trods ligheden ikke er identisk med Henrik Bjelke. Hans stil, „et altid beredvilligt analogt og katalogt ordvalg i sin ødselhed" (Bjelke 1986:9), kommenteres, og det erkendes, at "automatskriften, den evigt 'forvrøvlede' indre stemme ikke bringer ham nærmere ham selv" (Bjelke 1986:26).

Bestræbelsen på at af-autorisere fortællingernes udsagn er tydelig. Ved at skildre den livshistoriske fortælling som én blandt flere mulige kryber Bjelke uden om en alt for håndfast oversættelse af det singulære til lineære og iterative former (cf. Tygstrup 1994:84):

Hvad for en version skal vi tage, søn af en veg verdensfjern organist og en irsk katolsk matrone hvis monomane ønske om en pige efter fem besværlige drengefødsler jeg blev tævet til at opfylde, eller hvad med denneher, søn af en flygtet østpreussisk urmager der stod i forhold til sin svigersøn og en litauisk fiskerdatter, der havde slået sin mor ihjel, nej minder for meget om roman, vi tager en der er som syet til nouvelle école freudienne, søn af en dansk tyskerhoppe, der efter krigen blev klippet skaldet, fik sværtet hagekors i hoved og røv og gennet gennem gaderne, og en homosexuel klaverstemmer. ${ }^{9}$ Fede traumer mand, som en sagde, fede traumer. (Fede?) Nå. Jeg får heller aldrig, skriftligt i hvert fald, fortalt om min mandschauvinistiske Henry Miller-Jack Kerouacungdom i 50'erne. (Bjelke 1980:12 f.) 
Få sider efter en opstemt idealisering af Hectors forhold til Claus og Beate følger i Solo nolo en cool klassifikation af det som „lidt præpubertetisk ømhed“. De samme begivenheder beskrives med flere stemmer: 10 hvad der lyrisk besynges, kan snart nok så prosaisk diffameres. Den erklærede hensigt - at fatte et liv, "hvis skæbne det netop er, at valget, sproget, som skulle dementere skæbne, forråder en til skæbnen. Og så er jo alt, hvad der kan være tilbage at gøre: så akkurat som muligt at fatte og udtrykke den, iført de sproglige dragter, som forræderiet vitterligt foregår i“ (Bjelke 1986:41 f.) - kræver en objektiverende repræsentation af et sprog, der ikke er fortællerens eget.

Derfor rummer Bjelkes tekster mangfoldige citerede diskurser. I Trap f.eks. en juridisk og en psykoanalytisk. Intertekstualiteten er ubændig, i Hundrede postkort fra Helvede mødes rock og religiøs digtning, filosoffer som Nietzsche, Sade og Vaihinger, digtere som Miller, Beckett og Blicher (for ikke at tale om James Samuel Naboyckott, der som bekendt har skrevet enten Jolisses, Molyne eller Lulyta), psykoanalytikere som Irigaray og Ferenczi og en del andre. Allusionsteknikkerne er mangfoldige: direkte citat, referat, travesti, parodi, pastiche (cf. Egebak 1989) osv. Bjelke har lært af avantgardens montage- og collageteknikker.

Romanen hører hjemme i en polyglot verden, fortæller Bakhtin (1981:12). Den hollandsk-danske Hector fra Solo nolo er bastard, ligesom teksten er det. Flersprogetheden er demonstrativ, der citeres på engelsk, tysk, fransk, spansk, latin, hele afsnit er på udenlandsk. Modersmålet er selv en slagmark. Hybridiseringer og renselsesfors $\varnothing g$, centraliserende og decentrerende tendenser (Bakhtin 1981:66 f.) kriges her. Hos Bjelke er stillejer, vokabularer, genrer, rum, tider, handlingstråde, verdener altid i flertal. Romanerne svinger mellem sentimentalitet og platte kynismer, stringent fagsprog og eksalteret lyrik. Berettende fiktion glider sammen med essayistik, forfinede skønsange med skatologiske orgier. Visionære associationer møder mediefiktioner, citater fra mange tusind års kulturhistorie og en slags ydre realitet. Teksterne er polymorfe. 
Bjelke skriver romaner. Han er en af de danske forfattere, der allermest emfatisk lever op til Salman Rushdies karakteristik af genren:

De sataniske vers hylder hybriditet, urenhed, blanding og den forvandling, der følger af nye og uventede kombinationer af mennesker, kulturer, tanker, politiske ideer, film, sange. Den jubler over bastardiseringen og frygter det Renes absolutisme. Blanding, sammenrod, lidt af dette og lidt af hint, det er på den måde det nye kommer til verden. [...] Romanen er [...] en kærlighedssang til vore bastard-jeg'er. (Rushdie 1992:247 f.)

\section{Fremmedlegemer}

Jeg sluger alt fra nu af. Jeg er fagocyt (Bjelke 1970:208)

Forkærligheden for det heterogene og hybride er tidstypisk. ${ }^{11}$ Men Bjelke er fri for den snert af renfærdig politisk korrekthed, der præger Peter Høegs opgør med vor vestlige hybris - sammenlign beretningen om højeresteretspræsident Ignatio Landstad Rasker med Solo nolos besyngelse af den homoseksuelle ekstase. Bjelkes fantasmer er ucensurerede og urene, her er mere flip, galskab og idiosynkrasi. Mere, man kan få galt i halsen, flere fremmedlegemer.12 Teksterne er bastarder - som vi selv er det: „det eneste, der flytter noget, er disse ømme, sårbare øjeblikke, hvor noget i en bog, en film, en melodi trænger ind og planter sig som en fremmed og dog ikke fremmed virus [...] vi forstår, at vi er nogen andre" (Bjelke 1986:35).

At det heterogene får lov at forblive et fremmedlegeme, er en æstetisk kvalitet. Kunsten redder noget af det amorfe, den gør vold imod, med over i formen: „Det, der knirker ved kunstværkerne, er lyden af gnidningen af de antagonistiske elementer, som kunstværket tragter efter at bringe sammen" (Adorno 1970:80, 264).

En spænding mellem inkorporation og afstødelse kendetegner Bjelkes poetik, og det placerer ham mellem modernismen hvis grænseafsøgninger, overskridelsesæstetik og alvor han 
deler - og postmodernismen. Skriften fortærer og integrerer alt ligesom fiskene i Trap:

Den ene fisk som er en kuffert sluger den anden, mindre, taske, der igen sluger en pung. Enterosolubile. Solubile. Slub. Salub. Salubile. Opslugt. Oggslubt. (Bjelke 1970:207)

Men den er også eksorcistisk: ${ }^{13}$

Jeg hader folk, der skriver uden at drive djævle ud [...] Ingen er engle og det burde være almindelig kendt. Deres ragelse, kopieringer af en virkelighed der præsumeres at være ægte, mens den er falsk, fordi den ikke er nødvendig, så dødsensnødvendig for frembringeren, som den er for den frembringer, der først kan komme til existens gennem det at frembringe skriften. Så hans væren bliver realiseret i det skrevne og ikke et øjeblik før. (Bjelke 1980:56)

Den inkorporerende gestus deler postmodernismens forhold til traditionen: „en svinsk tagen for sig af varerne i et kæmpestort supermarked af kulturgods" (Bjelke i Skyum-Nielsen 1982:226). Denne altædende skrift står imidlertid ikke uproblematiseret.

Traditionen er nemlig ikke kun et tag-selv-marked, men også en losseplads. Trap lægger ud med en beskrivelse af de lugte, der hænger ved en gammel lejlighed; senere beskrives jura-studiet som hjernevask i uddøde discipliner, "under hvilken han opfordres til at brække samfundets ekskrement, som han har fortæret, op" (Bjelke 1970:122). Recirkulation og genbrug opfattes ikke helt så positivt som i dagens miljødebat, i det mindste ikke, når det gælder tegn og betydninger: „Deter ikke engang cirkulation, det er perverteret versatil trafik af affaldsstoffer. Fortæring kan aldrig blive naturlig, når genstanden er andres og derefter eget opkast" (Bjelke 1970:159).

En versatil trafik af noget, andre allerede har haft i munden, det kunne være en definition på sproget: der er intet singulært, jomfrueligt privatsprog. At andre altid har været der, er et vilkår, som postmodernismen - og romanen i Bakhtins og Rushdies beskrivelse - accepterer. Modviljen mod fylde (Bjelke 1970:161) og forsøget på at sprænge historiens kontinuum for at nå frem til et 
sprogløst „nærhedsøjeblik“ (Bjelke 1970:144) synes derimod i slægt med modernismens dyrkelse af det nye. Længselen efter et nulpunkt, der kan være en ny begyndelse (cf. de Man 1986:148)14 ytrer sig i forestillinger om uddrivelse, overskridelse, eksplosion og gennembrud. Revolutionen er også en moderne renselsesforestilling, snart verdens grundvold sig forrykker, som det hedder i sangen:

Hermed er det nye erobret \& gennembrudet udløser jordskælv af uro i fundamenterne, der sker jordskred, det brager \& knager, det ryster og mange jordskorper kastes mod hinanden som offer for underjordiske vulkaner (Bjelke 1970:212)

Modernisme og postmodernisme, afsondring (cf. Bjelke 1970:161) og indoptagelse er to konstante modaliteter i Bjelkes skrift. „Se og fortære, skrive og skide" (Bjelke 1980:55).

\section{Det urene}

Det urene skulle være et særkende ved romangenren. Det er konstitutivt for Bjelkes sprogpraksis - og samtidig et tilbagevendende motiv. Forfatterskabet demonstrerer en usædvanlig sans for marginer og mellemting, overgange og flossede grænseområder. Kroppens grænser, sindets, kønnets, identitetens, universets, det menneskelige og meningsfuldes randzoner. Med sine postkort fra „den skrøbelige grænse (borderline cases), hvor identiteter (subjekt / objekt etc.) ikke eksisterer eller kun lige gør det fordoblede, udviskede, heterogene, dyriske, under forvandling, forandrede, abjekte", skriver Bjelke sig ind i den tradition, hvori Kristeva placerer Céline: „Baudelaire, Lautréamont, Kafka, Georges Bataille, Sartre (Kvalme) eller andre samtidige kunne hver på sin måde have været førere på min nedstigning til navngivningens, det vil sige til den benævnelige identitets, helvede" (Kristeva 1980:207). ${ }^{15}$ Med Bjelkes ord: „vore bøger bliver landkort over vort pandæmonium" (1980:44).

Romanerne opsøger steder, hvor overgange og udvekslinger finder sted. På de første sider i Trap beskrives vægge, gulve, lof- 
ter og tøj som hinder, der kan være hele eller - hyppigere - hullede. Senere følger fantasier om et hyperbolsk stofskifte:

Værre, da jeg kommer forbi munddyngerne. [...] de åbner \& lukker sig i hver sin individuelle rytme, blotter tænder, ofte smukke, sluger vand og lukker sig idet vandet usynligt strømmer ud igen. Høbt. Hubt. Slubt. Obslubt. Øbt. Øbt. Muslinger. Lukkemuskler igang konstant. Ringmuskler. (Bjelke 1970:208)

Ikke sært, at Trap har så svært ved at slippe ud - ud af moderens symbiotiske favntag, ud af traditionen, den fastlåste identitet etc.

Grænserne er permeable og tvetydige. ${ }^{16}$ Bjelke opsøger passager fra en tilstand til en anden. Fra kaos til form og vice versa. Tilblivelse og opløsning. Opvågningen er en fødsel til form:

Jeg genoplever traumatisk fødslen ved hver morgens opvågnen fra edderkoppegårdens millionmundede fangenskab. Berøringen med dig forvandler mig fra den ret, der på insekternes kongelige regale hedder ufødt foster serveret uden hornkokon eller sejrsskjorte - til den organiserede existens, fast afgrænset af hud som fint læder og gryende orienteringsevne (Bjelke 1980:21)

Hundrede postkort fra Helvede er i øvrigt fyldt med fantasier om en destrukturering, der mest af alt minder om Freuds dødsdrift eller Batailles erotisme. Kapitlet "Tung sult" beskriver en drift mod det kontinuerte: 17

Tilbage er kun en flyden ind i modernattens bordeauxfarvede nihilisme [...] dens afstrukturerede impulsers nigersorte enevælde af ekstaser og mysterier i deres besynderlige styrtregn af prygl, pis og fødsler af ukendte deformiteter. (Bjelke 1980:49)

Den sidste formulering fører os definitivt ind $i$ et heterogent register. Bjelke skriver med forkærlighed om det tabuerede, makabre og lave. Om de socialt udstødte, flygtningene, ${ }^{18} \mathrm{om}$ „psykens mørkeside" (Bjelke 1980:112), det forbudte og ækle (dog uden voldsom væmmelse), om seksuelle fantasmer og perversioner, om det grimme og om det sublime. Mødet med altet og andetheden finder sted på det negatives præmisser, smertens, dødens, 
snavsets. Skriften er selv smittet af galskab, vold og en analitet, der har samme ekstatisk jegopløsende præg som den, Kristeva ser hos melankolikeren, men som næppe kan kaldes aferotiseret: „det er hele den depressives jeg, der opsluges i en analitet, der er aferotiseret og dog jublende, idet den er blevet vektor for en fryd, der indgår forbindelse med den arkaiske Ting, som ikke opfattes som betydende objekt, men som element i jeg'ets grænser. For den depressive er Tingen såvel som jeg'et fald, der river ham ned i det usynlige og det unævnelige. Cadere. Affald, kadavre helt igennem" (Kristeva 1987:25). Fald, affald og ekskrementer har en fremtrædende plads i Bjelkes prosa.

Den jublende analitet møder vi f.eks. i „Der grosse Kranke” fra Solo nolo. ${ }^{19}$ Temaet er skidt. Afføringen og det under neglene. Renlighedstræningen i kort repetition: „Spyddet, angsten, resultatet, loven, roen, regulationen". Identiteten beror på det udstødte: „Skidtet er ham, det fødte, verden, jorden er ham til han mister den, kommer af med affaldet, med sig". Temaet knyttes til det ubevidste, og til skriften, der også har noget at trykke ud. Afvigelsen og nedværdigelsen indgår i en frydefuld higen hen mod det Reelle:

Vi er oversættere af smerte til væren, erstattere af erstatninger. Regulation, rotation, ild, lyn, rytme, lyd og kode for et sprogløst antibabel af foragt og tavshed, af sjælelig samsvingen, altings tavse smerte, altets smerteophævende smerte, flint mod flint, skidt værre end gnisten, muskel mod muskel, skidt værre end 220 volt sæd, neglerensere mod neglerensere, hinandens bødler. Me Tarzan, you me. (Bjelke 1986:23 f.)

Lyn, ild og gnister er emblemer for det sublime, der altså kun nås via det lave.

\section{Ekstase}

Ting viger, grænser, begreber, fællesskaber viger. (Bjelke 1986:141)

Romanerne opsøger den tærskel, hvor alle grænser bliver ophævet. De verbale excesser stiler mod en ekstase, hvor subjektet 
ikke længere står formende, spejlende og identificerende over for et objekt, det er adskilt fra. Tværtimod er det selv provisorisk stanset ud af den forskelsløse kontinuitet, Bjelke beskriver med myten om urhavet, hvor ,afkast, deling, spaltning o.s.v. ikke var meningsbærende instinkter" (Bjelke 1980:130). Gennembrudsfantasierne er rettet mod en uplettet præsens. Sprogløst og tavst skal nærværet være - hvad der må være lidt af et paradoks for en ordkunstner. ${ }^{20}$

Ekstasen er en mystisk enhedsoplevelse. Subjektet er ophævet, tid, rum, bevægelse er det også i en symfonisk ,parring af ingen med intet og alt med alt" (Bjelke 1980:48). Driften ophøjes til

et gotisk ridt af hove gennem drømmenes dæmpede muld, hvorhen, hvor, hvornår gennem tidernes deltaer, ikke mere vejr, ingen ord om vejr, ingen ord om ingen ord, ingenting om ingenting: ingen regn på regnen, ingen dug på duggen, ingen drift i drift, men kun svingende trommende strømmende pumpende åndende ud $\mathrm{i}$ ingen drift af ingenting mod ingenting. (Bjelke 1980:49)

Til mystikkens nunc stans svarer Bjelkes nul-tid, ingen-tid (f.eks. Bjelke 1980:134, 141). Den er latterens, orgasmens, legens, kunstens og skriftens (Bjelke 1986:57 f.). Det hele iscenesat i en kosmisk myte: „bestandige ekkoer fra et pulserende univers af glødende, granatrøde aminosyrer i uforklarlig evig bevægelse gennem nedbrydelig sten, gennem kemisk nat, gennem udslukt tid og gennem de vandrende syner af en upunktlig eros, som grådigt fortærer sig selv uden nogensinde at forsvinde, uden nogensinde at mættes" (Bjelke 1980:49).

\section{Dæmpede excesser: Togplan for Otto}

Den rablende verbalisme, det hymniske, hybride og urene, lovprisningen af det lave, tabuerede og heterogene, alle de ubundne energier udgør en hovedstrøm i Bjelkes romaner. Afstrukturering og overskridelse favoriseres frem for fast form. I de seneste værker, topografisamlingerne og Togplan for Otto, holdes exces- 
serne imidlertid i ave. De er ikke mere mål i sig selv, men derimod den centrale impuls, der holder teksterne gående.

Togplan for Otto er en mere traditionel udviklingsroman end Trap, Saturn og Solo nolo. Fra første færd får vi flere forankringer. Allerede på første side præsenteres tid, sted og personer: Edel og Otto sidder i toget fra Århus til Frederikshavn januar 1941. De præcise slægts- og kulturhistoriske rids giver så klare konturer af en socialisationshistorie, at man kunne have Bjelke mistænkt for at ville efterleve Goethes krav til biografiskriveren om at forstå individet i forhold til dets tid. Bogen fremstiller den sociale og familiære orden, Otto lige fra fødslen indskrives i. Kulturhistorien er eminent velegnet til at generere betydninger - der er ingen verbale skranker for beretningen om victorianernes indskrænkede seksuelle spillerum. Men samtidig tilføjer den beretningen en objektivitet, som gør, at alt ikke bliver første person ental, og som dermed forhindrer det decentrerede subjekt $\mathrm{i}$ at sprede sig over hele teksten.

Med en gængs allegori peger titlen på det, den livshistoriske fortælling ofte har drømt om at finde: en rute gennem livet, en rød tråd - et plot. Titlen antyder, at meget, for meget måske, på forhånd er lagt på skinner. Otto må bære forældrenes uløste konflikter og den danske kulturs byrder. ${ }^{21}$ Togplan for Otto er en forkrøblingshistorie. Et fikspunkt er som i Trap moderens manglende kærlighed: „Han var blevet tabt og tabt atter og atter, i sneen, for sjov, i mangler, i savn, i fravær, i universel skræk, i lyse fløjlshynder med laksefarvet betræk i moderens verden, hvor der manglede ryg" (Bjelke 1990:104).22

Trap, Hundrede postkort fra Helvede og Solo nolo havde lignende narrative grundmønstre, konfliktstof og udviklingsforløb. Også de var psykobiografier, fortællingen havde blot en mindre fremtrædende plads. Barndommens kroniske utryghed gjorde således Trap indelukket. En vagtmand formulerer hans konflikt og en mulig dannelsesvej: „Hvad foretager De Dem her muttersalene i bælgmørke [...]? Kan De så se at komme ud!" (Bjelke 1970:196). Trap må knække barndommens æggeskal. Frigørelsen sker i brud. Plottet er katartisk, Bjelkes helte skal renses fra fortiden. "Jeg er ikke mig", konstaterer en af dem (Bjelke 1980:85). 
Omslag, opbrud og omvending er vejen frem, udkast til en åben identitet: „Hector var ikke til at have, hverken i det ene eller det andet sprog. Eller i noget sprog. Han var et standende forsøg på at blive til. Blive til en eller anden" (Bjelke 1986:41). Dannelse anno 1986.

Socialisationshistoriens episke struktur medvirker til at binde de affektive og retoriske energier. Kontrollen er i Togplan for Otto større end i de tidligere romaner. Her er mere prægnans og færre synonymophobninger. Ordene er ikke trådløse, for de er integreret i en episk orden. Excesserne er dæmpede. "Lyn under sne" hedder bogens første del. Det sublime som den lynende skæbne, romanpersonerne bliver snydt for. Spændingen mellem ordene og den store kontinuitet, mellem ekstase og epik gengives smukt i billedet af toget i sneen - en vinterrejse fra Århus til Frederikshavn og samtidig en allegori om passagen fra liv til døden, hvor alt går i hvidt:

Korte i en lige linje gennem den forskelsløse, hvide flade af sne og efterlod i sit kølvand en sort, lige dobbeltstreg af spor. Og miraklet (at punktet strækkes ud til den lige linje) blev realiseret permanent: selve farten fandt et spor under sneens sporløshed. (Bjelke 1990:9)

Livet ridser en forskel i tidens kontinuum, ligesom skriften sætter spor i papirets hvide flade.23 Begge er bevægelser i intet. Det udtrykkes i billedet af sneploven, hvis ,spydspids som intet skadede og kun byttede om på noget vejrlig, forvandlede stilleliggende sne til en springende fontæne, endelighed til foreløbighed, væde til luft" (Bjelke 1990:86). Livet og fortællingen forenes $i$ et enkelt forløst billede.

Lyn under sne. Perennerende stilstand og begær efter opbrud. Ottos mor Edel vil ,noget andet, enten noget stærkere eller noget modsat" (op. cit. p. 13). Med sine indestængte ønsker er hun offer for en selvpålagt tvang, der gør livet mindre, end det kunne være: „længslerne var udenforrettede - og uforrettede“ (op. cit. p. 121). Ekstasen er nu det, der gives afkald på. De stærke energier forbliver under overfladen, glemte eller fortrængte. 
På første side præsenteres en elegant kvinde i et tog. Over hendes hattepuld hænger et fotografi af „en lysebrun gade i en købstad med brosten og ingen trafik, solbeskinnet, et billede på uskyld, forældet, skønt det kunne være taget fem år tidligere" (op. cit. p. 9). Uskyld, forældet: subversionen af billeder er et af bogens vigtigste greb. Under overfladen lurer katastrofen. Den bryder ikke igennem, men skaber en "egen lille akavet balance" (op. cit. p. 23), der konstant er på nippet til at kamme over.

Den camouflerede katastrofe udstilles af bogens sprogholdning. Den glatte, overbærende stil skjuler moderens forsømmelse af Otto: „Så meget holdt det gamle par af lille Otto, at han næsten altid var hos dem" (op. cit. p. 91). Ondskab, brutalitet og lidelse retoucheres til ren hygge:

til siderne i samme højde fortsatte den hvide flade, bestående af løs nyfalden sne. Herud smed en af de rare soldater nu sin kasket og Edel sagde, „,Otto, kan du hente Gerhardts kasket!" Otto stavrede ud gennem sneen og faldt naturligvis igennem den lose sne og stod pludselig i sne til ørerne og stak i et vræl som imidlertid blev overdøvet af støjende latter fra de voksne (op. cit. p. 90)

Konfliktstof camoufleres, onkel Ludvigs homoseksualitet f.eks. men mellem linjerne sender den implicitte forfatter signaler til læseren om at stryge teksten mod hårene. Stilen er nemlig pastiche, andres ord, f.eks. markeret af det lille 'naturligvis'. Her lykkes det virkelig at fatte og udtrykke en skæbne „iført de sproglige dragter, som forræderiet vitterligt foregår i".

I Togplan for Otto sætter Bjelke udtrykkeligt. fokus på repræsentationen. Han gengiver erindringsbilleder, drømmebilleder og fortidige diskurser, ikke en rå virkelighed. Ottos fars barnehjem iscenesættes som et idyllisk genrebillede: „om søndagen gik Herrerne på jagt og kom gerne hjem med en hare, som bedstemor havde sin egen opskrift på at lave. Man holdt høns og spiste friske æg, og Varde $\AA$ flød blank og ren i den stille sommeraften" (op. cit. p. 47). Ironisk udstilles de sproglige verdensbilleder, der klemmer personerne fast i alt for små roller: „Arnold levede op til sin generations bedste idealer og meldte sig 
sammen med andre unge i firmaet ind i en roklub, der lå lige ved siden af studenterroklubben" (op. cit. p. 68).

Fortælleren er plastisk. Han taler humoristisk underdrejet om Hansens stolthed over ,at have fået hjørnelejlighed og være blevet formand i en åndelig forening af kvinder" (op. cit. p. 23), men han kan også være myndigt analyserede, næsten docerende, når han begrebsligt forklarer forhold, de omtalte personer ikke selv kender til, og som læseren heller ikke får lov til at tænke sig til: "her havde hendes selvrådighed åbenbart intetanende overskygget hendes ubevidste længsler. Hun rettede ikke bevidst sine længsler mod barnet, som var og blev et appendix eller en fortsættelse af hende selv på godt og ondt" (op. cit. p. 13). Ofte er han bredt malende og autoritativ i en form, der på en gang er olympisk hævet over verdenshistorien og nedsunket i sproget: „Man må forestille sig den form for uskyld, der rådede i sjælen på den generation af unge mænd i 1920rne, hvis mødre havde tilhørt en race af storbarmede, bredbagede, langskørtede, korsetterede fruentimmere" (op. cit. 33).

Her må ordene formodes at være fortællerens egne. Nok så karakteristiske er imidlertid de teknikker, hvormed han mimer andres diskurs. Ved den hyppige brug af dækningsteknik når Bjelke et alternativ til den hæmningsløse ekspressivitet. Stemmen indoptager andres ord.24 Med en opmærksomhed på sproget svarende til den, man finder hos forfattere som Seeberg, Hultberg og Smærup Sørensen, når Bjelke en ironisk objektivitet med plads til både indlevelse og distance. Den dæmmer op for det private, monomane og docerende, der ofte var en ikke æstetisk forløst bagside af den verbale ekvilibrisme. 


\section{Noter}

1. I Rygternes atlas står følgende værker anført som romaner: Trap (1970), Saturn (1974), Hundrede postkort fra helvede (1980), To mænd (1982), Aurora Karamzin (1982), Solo nolo (1986) og Togplan for Otto (1990). Min indkredsning af Bjelkes romanpoetik refererer primært til Bjelke 1970, 1980, 1986 og 1990.

2. Opmærksomheden på ordet ser Brian McHale som et af de postmoderne greb, hvormed en tekst udstiller sin egen ontologiske differens; $c f$. kapitlet „Words” (1987:131-175).

3. Udtrykket stammer fra Musil og citeres efter Tygstrup (1994:83), der også har inspireret overvejelserne over punkt, linje og flade.

4. Ordet er ikke tekstens mindste enhed. Bjelke dyrker ikke kun ord, men også o'er, cf. titler som Yoyo, Togplan for Otto, postkort, topografier, radiotango, prodrom etc. I Solo nolo optræder frk. Koonig, "de to o'er i hendes navn som blinde spejle, som dobbeltløbede riffelmundinger, som glasøjne" (Bjelke 1986:40).

5. Stavelser kan der også byttes rundt på. Et eksempel på sproglegen i Trap: „,...Intersolubile mekanismer. Solid. Forræd. Sorræd. Forlid. Forlide sorræderier. Mekasolubile internismer. Forræderiske solidariteter" etc. (Bjelke 1970:219)

6. Finn Stein Larsen kommenterer dette sted 1987:264 f.

7. Tage Skou Hansen var i sit forsvar for prosaen inde på lignende tanker: lyrikeren er alene med sig selv, sin sjæl og sin udtrykstrang, prosaisten træder derimod tilbage og lader ikke sine ord tiltrække sig opmærksomheden for deres egen skyld, men digter menneskeskikkelsen "ud i begivenheder med andre skikkelser" (Skou Hansen 1950:503).

8. Temaet har været der lige siden Første person ental. Hovedpersonen $\mathrm{i}$ Bjelkes første roman, Trap, er "opvokset i et miljø med sparsomme interpersonelle kontakter" (Bjelke 1970:105). Otto Rybalt skaber i den sidste tilsvarende „en harnisk omkring sig af uigennemtrængelig verbositet" (Bjelke 1990:127). Cf. også interviewet i Skyum-Nielsen 1982:232.

9. Historien kan genfindes i Trap og i Togplan for. Otto.

1Q. Dialogen kan etableres via tekstens udenværker. I Hundrede postkort fra Helvede beskrives en homoerotisk forløsning. Overskriften "A Woman (or two) left lonely" (Bjelke 1980:23) siger med henvisning til Janis Joplin noget om frihedens bagside. 
11. Den postmoderne roman spørger til begreber som „autonomi, transcendens, vished, autoritet, enhed, totalisering, system, universalisering, center, kontinuitet, teleologi, lukning, hierarki, homogenitet, singularitet, oprindelse", siger Linda Hutcheon (1988:57).

12. Cf. Bakhtins beskrivelse af middelalderens latin som et sådant „fremmedlegeme, som invaderede de europæiske sprogs organisme. Og gennem middelalderen afstødte nationalsprogene [...] dette fremmedlegeme. [...] Afstødningen af det fremmedfødte hellige ord var en dialogiseret operation" (Bakhtin 1981:77).

13. Med sin eksorcistiske etos og modernistiske alvor placerer Bjelke sig lige langt fra en postmoderne glad nihilisme og en bakhtinsk latterkultur.

14. Nulpunktet er tillige et centralt tema. Trap identificerer sig med kloakker, død, intethed, inerti og goldhed (Bjelke 1970:175). Hans verden er fremmed, absurd og ødelagt. Fornemmelsen af tomhed - ikke for ingenting hedder han A.T. Trap - og uvirkelighed er overvældende. Intet synes kortlagt: „Uden noget på, så at sige, går han gennem gader \& parker han ikke kender og uden nogen synderlig veludviklet orienteringsevne" (Bjelke 1970:209). Hovedpersonen i Hundrede postkort fra $\mathrm{Hel}$ vede har næppe de mest elementære koordinater tilbage: „Jeg opholdt mig ved meget få facts. Jeg var her, hvad de tre ord så end betød hver især, hvis de overhovedet længere betød noget" (Bjelke 1980:90).

15. I Solo nolo betegner Hector tilsvarende modernister som Wagner, Proust, Joyce, Eliot, Pound og Beckett som "store grænseafsøgere" - og som „store rodehoveder" (Bjelke 1986:55).

16. Bjelkes bøger opsøger interferenserne mellem sprog, psyke og samfund. Og mellem biografi, fiktion og personlig mytologi. Referencerne til Bjelkes liv er åbenlyse (hovedpersonerne er hyppigt mænd, født sådan ca. 1937, de studerer jura - Trap aftrykker ligefrem en juridisk redegørelse, afgivet af forfatteren - arbejder med flygtninge etc.). Men romanerne henviser også til hinanden: det ikke-elskede barn, den autistiske voksne og det homoseksuelle gennembrud er tilbagevendende motiver.

17. Bjelke refererer andetsteds til den ikke-menende side af sproget, Kristeva har kaldt det semiotiske: „prosaens anatomi er ligesom ganens upersonlige riller og rytmer i principielt endeløs kontinuitet" (Bjelke 1980:66). 
18. Cf. Bjelke 1980:124: „fordi man selv var ådsel, var en pr. definition fordrevet, permanent mental landflygtig, ontologisk landflygtig".

19. Kapitlet genskriver en passage fra Trap, cf. Bjelke 1970:127 f.

20. Bjelkes forestillinger om en ren animalsk id-skrift har Egebak med rette anfægtet. Begæret efter et nærvær hinsides al symbolaktivitet kan først opfyldes i døden, der gør os til kadavre blandt andre dyriske kadavre (Egebak 1988:45).

21. I "Et sted som ingen ved" hedder det tilsvarende: „Han kender resten af dette spædbarns kommende skæbne, der ikke står til at ændre, og han ved, at dette barn vil blive udsat for berøvelser". Mangler og berøvelser er vore alles vilkår, hvis man skal tro Lacan. Men Bjelke går videre: „Og ville man spørge, hvorledes han kunne vide, hvad der skulle ske med dette barn (for ingen kan jo kende begivenhederne i en fremtid, som ikke er indtruffen), ville svaret være, at dets fremtid forlængst var indtruffen, at den allerede var ovre" (Bjelke 1992:96 f.).

22. De "begåede krænkelser af et lille liv" gøres andetsteds til universel myte: „en ny mor piner et nyt barn i vandkanten hele den lange ihjelslåede eftermiddag" (Bjelke 1986:34). Bjelkes romaner skriver alle på omtrent den samme individuationsmyte.

23. Senere hører vi om "sneplovens fyldepenneagtige spids" (Bjelke 1990:131). Passagen er foregrebet i Hundrede postkort fra Helvede: „gyser allerede af horror vacui i sjælelige volter ved tanken om mit dødsøjeblik, da jeg med spidsen af pennen frembringer en tynd mørkeblå streg øverst i det øverste arks ulinierede snelandskab" (Bjelke 1980:60). Og den parodieres i kapitlet "Anatomi er skæbne”, hvor sneen erstattes af Edels „vældige hvide flæsk", en bleg bag, ",hvis balder var trykket sammen, så revnen dårligt nok var en revne, men snarere en sitrende linje, der blot markerede en adskillelse". De hårde ord står nu i modsætning til det bløde kød; de svarer til pilene i den efterfølgende redegørelse for Ottos bueskydning (Bjelke 1990:95 f.).

24. Trods den proklamerede polyfoni kunne de forskellige stemmer i de tidligere romaner lyde påfaldende ens. 


\section{Henvisninger}

Adorno, Th. W., 1970, Ästhetische Theorie. Frankfurt a.M. .

Bakhtin, M. M., 1981, The Dialogic Imagination. Austin 1992.

Bjelke, Henrik, 1970, Trap. Fredensborg.

Bjelke, Henrik, 1980, Hundrede postkort fra Helvede. Viborg.

Bjelke, Henrik, 1986, Solo nolo. Viborg.

Bjelke, Henrik, 1990, Togplan for Otto. Kbh.

Bjelke, Henrik, 1992, Rygternes atlas. Syv topografier. Kbh.

de Man, Paul, 1986, "Literary History and Literary Modernity“. In:

Blindness and Insight. 2. udg. London.

Egebak, Niels, 1988, „Den falliske skrift og Id-skriften“. In: Galskabens metoder. Viborg.

Egebak, Niels, 1989, „Pastichen som kunstnerisk princip - i anledning af Henrik Bjelkes seneste novellesamling“. In: Bogens verden nr. 41989.

Hansen, Tage Skou, 1950, „Forsvar for prosaen“. In: Heretica. 3. årg.

Hutcheon, Linda, 1988, A Poetics of Postmodernism. History, Theory, Fiction. N.Y. \& London 1992.

Kristeva, Julia, 1980, The Powers of Horror. An Essay on Abjection (Pouvoirs del'horreur). N.Y. 1982.

Kristeva, Julia, 1987, Soleil noir. Dépression et mélancolie. Paris.

Larsen, Finn Stein, 1987, „Om at være i brændpunkter. Ti lyn-nedslag i den nyeste danske prosa“. In: Bogens verden 69:4.

McHale, Brian, 1987, Postmodernist Fiction. London and N.Y. 1993.

Rushdie, Salman, 1992, Fantasiens hjemlande. Essays og kritik 1981-1991. Århus.

Skyum-Nielsen, Erik, 1982, Modsprogets proces. Viborg.

Tygstrup, Frederik, 1994, „Punkt, linie, flade. Refleksioner over fortælling og erfaring“. In: $K \in \mathcal{E}$ K 76 (21. årg. nr. 2): „Det narrative“. 
